\title{
THE CONSTITUTIONAL CHALLENGES THAT THE BREXIT NEGOTIATIONS HAVE CREATED IN THE UNITED KINGDOM: AN OVERVIEW
}

\author{
ALLAN F. TATHAM' \\ Universidad CEU San Pablo \\ allanfrancis.tatham@ceu.es
}

\section{Abstract}

The Brexit negotiations raise a myriad of challenges for the constitutional system of the United Kingdom. This study focuses its attention on those that have appeared in the first phase: the constitutionality of the UK's notice of withdrawal (under art. $50 \mathrm{TEU}$ ) and how it has affected the relationship between parliamentary sovereignty and the exercise of prerogative powers; the contents of the EU Withdrawal Bill and its possible extension of government law-making without parliamentary scrutiny as well as its implications for the devolved governments; and, lastly, the sensitive issue of the border of Northern Ireland with the South.

1 Facultad de Derecho, Universidad CEU San Pablo. The author would like to thank the two anonymous reviewers for their helpful and incisive comments. The usual disclaimer applies. The legal situation stated as of 9 March 2018. 


\section{Keywords}

Brexit; EU withdrawal; parliamentary sovereignty; prerogative powers; EU law; devolved government; Northern Ireland border.

\section{LOS DESAFÍOS CONSTITUCIONALES INTERNOS QUE LA NEGOCIACIÓN DEL BREXIT CREA EN REINO UNIDO: UNA VISIÓN GENERAL}

\section{Resumen}

La negociación de brexit plantea un sinnúmero de desafíos para el sistema constitucional del Reino Unido. Este estudio centra su atención en los que aparecieron en la primera fase: la constitucionalidad de la notificación de retirada del Reino Unido (en virtud del art. 50 del TUE) y cómo afectó la relación entre la soberanía parlamentaria y el ejercicio de poderes "prerrogativa»; el contenido del proyecto de ley de retirada de la UE y la posible ampliación de la capacidad legislativa gubernamental sin control parlamentario, así como sus repercusiones para los gobiernos descentralizados; y, por último, el tema sensible del estatuto de la frontera de Irlanda del Norte con la República de Irlanda.

\section{Palabras clave}

Brexit; soberanía parlamentaria; poderes de "prerrogativa»; gobierno descentralizado; frontera Irlanda del Norte.

\section{LES DÉFIS CONSTITUTIONNELS QUE LES NEGOTIATIONS DU BREXIT ONT CRÉÉ AU ROYAUME-UNI: UN APERÇU}

\section{Résumé}

Les négotiations du Brexit soulèvent une myriade de défis pour le système constitutionnel du Royaume-Uni. Cette étude s'intéresse à ceux qui sont apparus pendant la première phase: la constitutionnalité de l'avis de retrait du Royaume-Uni (au titre de l'art. 50 TUE) et ses effets sur la relation entre la souveraineté parlementaire et l'exercice des pouvoirs de prérogative; le contenu du projet de loi sur le retrait de l'UE et de son extension possible des pouvoirs législatifs du gouvernement sans contrôle parlementaire, ainsi que ses implications pour les gouvernements décentralisés; et, enfin, la question sensible de la frontière entre l'Irlande du Nord et la République d'Irlande.

\section{Mots clés}

Brexit; souveraineté parlementaire; pouvoirs de prérogative; gouvernement décentralisé; frontière de l'Irlande du Nord. 


\section{SUMMARY}

I. INTRODUCTION. II. THE CONSTITUTIONALITY OF INITIATING WITHDRAWAL: 1. Background. 2. Parliamentary sovereignty and EU law: 2.1. Parliamentary sovereignty pre-Miller. 2.2. Royal prerogative. 3. The Miller case: 3.1. Parliamentary sovereignty in Miller. 3.2. Exercise of prerogative powers for EU withdrawal not permissible. III. THE NATURE OF EU LAW BEFORE AND AFTER BREXIT: 1. Background. 2. Pre-Brexit: Miller case and the new understanding of EU law in the UK. 3. Post-Brexit: European Union (Withdrawal) Bill: 3.1. The need to ensure legal certainty and continuity. 3.2. Retained EU law. 3.3. Henry VIII clauses. IV. BREXIT AND THE IMPACT ON DEVOLUTION: 1. Background. 2. Impact on the UK devolution settlement in general. 3. Delaying withdrawal? 4. Amending devolved laws and repatriation of powers from Brussels. V. BREXIT AND NORTHERN IRELAND: 1. Background. 2. Free movement of persons and goods. 3. Belfast Agreement. 4. Proposed solutions. VI. CONCLUSION. BIBLIOGRAPHY.

\section{INTRODUCTION}

On 15 December 2017, the European Council finally decided that "sufficient progress" with the United Kingdom had been made in the first phase of the Brexit negotiations to warrant the start of the second (European Council, 2017: 1). Arriving at that point has caused much debate on the legal and constitutional issues surrounding Brexit (Eeckhout and Frantziou, 2017). In fact, these issues may seem to be, on occasion, rather obscure and difficult to grasp, even for a knowledgeable insider (Tatham, 2015). Given the broad and complex nature of the Brexit process (Armstrong, 2017), the present author has necessarily limited the focus of this study to a general overview of the main domestic constitutional issues for the United Kingdom, while remaining mindful of other sensitive legal issues that have been thrown up in relation to the EU generally (Mangas Martín, 2018), between the UK and the EU, e.g., citizens' rights (Mindus, 2017) as well as to other territories, e.g., Gibraltar (Del Valle-Gálvez, 2016-2017), in respect of which experts have already produced informative monographs (generally also Birkinshaw and Biondi, 2016; Hillman and Horlick, 2017). 
The aim of this study then is to dispel a little of the customary "fog" that surrounds the problems already encountered in the United Kingdom that may be of a broader, comparative interest: Section II of this study deals with the issues surrounding the notification of withdrawal, especially the UK Supreme Court's decision in the Miller case; Section III examines the nature of EU law, both pre- and post-Brexit, in the light of Miller and the proposed UK statute that seeks to "nationalise" EU law; Section IV looks at the potential impact on the devolved governments while Section V concentrates on Brexit and Northern Ireland. The study will conclude by considering, very shortly, ways of addressing the outstanding issues that have the potential to reconfigure the current UK constitutional arrangements.

\section{THE CONSTITUTIONALITY OF INITIATING WITHDRAWAL}

\section{BACKGROUND}

Any EU Member State is at liberty under art. 50(1) TEU to decide to withdraw from the Union "in accordance with its own constitutional requirements" (Tatham, 2012: 142-153). Moreover, under art. 50(2) TEU, such State "shall notify the European Council of its intention."

Within the novel UK context, the decision of the British electorate in the 23 June 2016 referendum (Castellà Andreu, 2016; El Cronista del Estado Social y Democrático de Derecho, 2016) was not in itself a decision under art. 50 TEU (Douglas-Scott, 2016: 1025). While the general rules governing referendums in the UK are contained in the Political Parties, Elections and Referendums Act $2000^{2}$, the details of the EU referendum itself were legislated into life by a separate statute, the EU Referendum Act 2015³: however, apart from the terms of the 2000 Act, no common practice has so far developed as to what other provisions are to be included in such an Act of Parliament. In fact, the 2015 Act contained no provision requiring the British government to implement its results or indicating a time limit for implementing a vote to leave the EU and thus amounted to an advisory as opposed to a mandatory referendum. (This may be compared to the referendum on the introduction of the alternative voting system for British parliamentary elections, the statute for which expressly provided that such a system would have come into force if

\footnotetext{
2 Political Parties, Elections and Referendums Act 2000, c. 41, sections 101-192, in particular.

3 European Referendum Act 2015, c. 36.
} 
there had been a majority of "Yes" votes cast in the referendum ${ }^{4}$ ). As a result of the 2015 Act, the 2016 referendum only permitted the electorate to express its opinion, before any legislation would be introduced.

Compliance with art. 50 TEU therefore required additional input from the British side (Mangas Martín, 2016: 431-435) in order to turn the result of the referendum into the requisite decision under art. 50 TEU. In this respect then, two issues came to the fore: (i) whether the British government on its own, using prerogative powers, could initiate the withdrawal process; or whether it needed the prior authorisation of the British parliament by statute before doing so; and (ii) whether the British government required the prior agreement of the devolved legislatures in Scotland, Wales and Northern Ireland before pursuing withdrawal. The following discussion will concentrate on dealing with point (i) above while point (ii) will be dealt with in section IV.3 within the context of the devolved nations.

\section{PARLIAMENTARY SOVEREIGNTY AND EU LAW}

The relevance of the issue of the prerogative powers has to be viewed against a backdrop of the notion of parliamentary sovereignty within the UK system and the domestic impact of EU law. Indeed the strength of feeling of those Brexiteers who wished to "throw off the shackles of the EU" in order to regain the UK's independence, especially its ability to frame its own laws, was one of the main issues of the 2016 referendum campaign.

\subsection{Parliamentary sovereignty pre-Miller}

The vote on EU membership by the UK and Gibraltarian electorate represented an expression of popular sovereignty. Unless arguably in respect of Scotland (Tatham, 2015: 11-14), the principle of popular sovereignty is not considered as a canon of the British constitution or its practice (Douglas Scott, 2016: 1020-1021). Rather, in the UK, sovereignty is considered as residing with the Crown in Parliament, and UK politics is founded on the principle of representative democracy.

In the United Kingdom, the doctrine that parliament is sovereign has been regarded as one of the fundamental principles of the unwritten constitution since it was laid down by the great constitutional jurists of the nineteenth century. The traditional concept of parliamentary sovereignty, in the eyes of the positive theory of law as expounded by Dicey, meant that there

4 Parliamentary Voting System and Constituencies Act 2011, c. 1, section 8. 
were no legal limitations upon the legislative competence of parliament and thus guaranteed the legal supremacy of statute (Tomkins and Turpin, 2011: 59). Defined in this way (Dicey, 1959: 39-40), parliament possessed: "Under the English constitution, the right to make or unmake any law whatever: and, further, that no person or body is recognised by the law of England as having a right to override or set aside the legislation of Parliament". The doctrine of parliamentary sovereignty thus consists essentially of a rule which governs the legal relationship between the courts and the legislature, namely that the courts are under a duty to apply the legislation made by parliament and may not hold an Act to be invalid or unconstitutional'5

The sovereignty of parliament in this respect was reaffirmed judicially by the England and Wales Court of Appeal in Manuel v. Attorney-General where Megarry V-C expressed grave doubts about the theory of the transfer of sovereignty as affecting the competence of parliament. He maintained that it was a fundamental of the British constitution that parliament was supreme and that, as a matter of law, the British courts recognised parliament as being omnipotent in everything except the power to destroy its own omnicompetence. Lord Bingham, speaking in Jackson in the House of Lords (as the UK Supreme Court was previously known), upheld the traditional view of the doctrine stating:" "The bedrock of the British Constitution is [...] the Supremacy of the Crown in Parliament." Yet, in that same case, Lord Hope cast doubt on the relevance of parliamentary sovereignty in the $21^{\text {st }}$ century, stating: ${ }^{8}$

Our constitution is dominated by the sovereignty of Parliament. But Parliamentary sovereignty is no longer, if it ever was, absolute... It is no longer right to say that its freedom to legislate admits of no qualification whatever. Step by step, gradually but surely, the English principle of the absolute legislative sovereignty of Parliament which Dicey derived from Coke and Blackstone is being qualified.

He noted rather that': "The rule of law enforced by the courts is the ultimate controlling factor on which our constitution is based"; and added ${ }^{10}$ : "Parliamentary sovereignty is an empty principle if legislation is passed which

\footnotetext{
5 For example, Lord Reid in the House of Lords case, Madzimbamuto v. Lardner-Burke [1969] 1 A.C. 645, 723.

6 Manuel v. Attorney-General [1983] Ch. 77.

7 R. (Jackson) v. Attorney General [2005] UKHL 56 [9].

8 Jackson [2005] UKHL 56 [104].

9 Jackson [2005] UKHL 56 [107].

10 Jackson [2005] UKHL 56 [120].
} 
is so absurd or so unacceptable that the populace at large refuses to recognise it as law".

Did EU membership alter the doctrine of parliamentary sovereignty? Some academics sought to evolve a new understanding of parliamentary sovereignty within the EU context (Wade, 1996) although this was contested (Bradley et al., 2014: 136; Tomkins, 2003: 120).

Due to the dualist nature of the British constitution with respect to international treaty law, the European Communities Act $1972^{11}$ (ECA) was subsequently enacted to make what is now EU law applicable in the national legal system, since without it, the Treaties and legislation would have had no internal effect. The Act is therefore not only the means by which parliament gave assent to the Treaties but also provides the legal foundation from which the supremacy, direct applicability and direct effect of EU law derives its status in the United Kingdom.

EU law has legal effect in the UK by operation of section 2(1) of the ECA. Moreover, the principles of supremacy and direct effect of EU law are imported into the domestic system by means of section 2(4) of the ECA which, somewhat opaquely, provides in part: "any enactment passed or to be passed, other than one contained in this part of this Act, shall be construed and have effect subject to the foregoing provisions of this section".

Until the 1990s, it was considered by the courts that section 2(4) laid down a very strong rule of construction that parliament was to be presumed not to intend any future statute to override EU law. In Macarthys Ltd. v. $S_{m i t h}{ }^{12}$, Lord Denning MR took a rule of construction approach to section $2(4)$ in trying to resolve the issue of whether to give priority of application to the UK or the EU norm (Khushal Murkens, 2017: 686) although his view of "construction" was broader than is usually taken in construing international treaties:

In construing our statute, we are entitled to look to the Treaty as an aid to its construction: and even more, not only as an aid but as an overriding force. If on close investigation it should appear that our legislation is deficient — or inconsistent with Community law — by some oversight of our draftsmen — then it is our bounden duty to give priority to Community law. Such is the result of section 2(1) and (4) of the European Communities Act 1972.

11 European Communities Act 1972, c. 68.

12 Macarthys Ltd v. Smith [1979] I.C.R. 785. 
In contrast, in 1991, Lord Bridge sought to solve the priority problem through a disapplication approach in Factortame ${ }^{13}$ in which the House of Lords disapplied the Merchant Shipping Act 1988 due to a putative conflict with EU law. Delivering the Opinion of the court, he stated: "Under the terms of the 1972 Act it has always been clear that it was the duty of a United Kingdom court, when delivering final judgment, to override any rule of national law found to be in conflict with any directly enforceable rule of Community law". In effect then every Act of Parliament had to give way (in the event of conflict) to EU law, brought into the UK legal system by section 2(1).

Yet it could also be argued that the court had disapplied the domestic statute because the ECA had told it to do so. Without the ECA, EU law would not have been law in the UK and would not therefore have been able to enjoy primacy over conflicting national law. These things could only occur in the UK system because the British parliament had willed it to happen by means of the ECA. So the law lords did not act in right of EU law as a new rule of recognition (i.e., the fundamental rule by reference to which all other rules are validated) or of any higher principle when setting aside the Merchant Shipping Act: they were ultimately obeying parliament's self-denying ordinance. Factortame could accordingly be seen more as an expression of parliamentary sovereignty rather than as a limitation on it.

Moreover, there is no suggestion in the ECA that there has been any attempt on the part of the legislature to entrench all or any of its provisions, to protect them against repeal by a future Act of Parliament. The ECA therefore proceeded on the basis of the legal sovereignty of parliament and is expressive of and subject to such principle of sovereignty. It had been enacted but there was no fetter on parliament which could still amend or repeal it. Such point was confirmed by section 18 of the European Union Act $2011^{14}$ that dealt with the status of EU law as being dependent on a continuing statutory basis: "Directly applicable or directly effective EU law (that is, the rights, powers, liabilities, obligations, restrictions, remedies and procedures referred to in section 2(1) of the European Communities Act 1972) falls to be recognised and available in law in the United Kingdom only by virtue of that Act or where it is required to be recognised and available in law by virtue of any other Act".

And what would the courts do where the UK parliament was to provide expressly in an Act of Parliament that such statute was to apply over an inconsistent EU law? According to case-law before Factortame (Tatham, 1993),

13 R. v. Secretary of State for Transport, ex parte Factortame (No. 2) [1991] 1 A.C. 603.

14 European Union Act 2011, c. 12. Emphasis supplied. 
Lord Denning in Macarthys ${ }^{15}$ and Lord Diplock in Garland ${ }^{16}$ had each intimated that, in such circumstances, the domestic courts would be required to give effect to the wishes of parliament. The implication, that parliament could assert its sovereignty while the UK was still a member of the EU, was not tested after Factortame. However in the more recent HS2 $\mathrm{case}^{17}$, Lords Neuberger and Mance in the Supreme Court observed ${ }^{18}$ : "It is, putting the point at its lowest, certainly arguable (and it is for United Kingdom law and courts to determine) that there may be fundamental principles, whether contained in other constitutional instruments or recognised at common law, of which Parliament when it enacted the European Communities Act 1972 did not either contemplate or authorise the abrogation".

They thereby seemed to suggest that the transfer of sovereignty was not complete even within the framework of EU membership (Ewing, 2017: 714).

\subsection{Royal prerogative}

The modern royal prerogative (Alder, 2009: 309-317) can be regarded as comprising the residue of the special powers, rights and immunities vested in the Crown which were originally privileges conferred on the monarch by medieval common law, rather than from a legal grant of authority by parliament (Douglas-Scott, 2016: 1027). These days, the royal prerogative allows ministers, acting in the name of the Crown, to take action without parliamentary authority in fields that fall within its scope, in so far as that field has not been effectively occupied by statute (Feldman, 2017: 217).

Prerogative powers exist by tradition and custom rather than in any official code (Douglas-Scott, 2016: 1027) or authoritative list although a 2009 Ministry of Justice report includes an annex that provides a list of what the government considered to be the existing prerogative powers (Ministry of Justice, 2009). Although not claiming to be authoritative or having any legal significance since only the courts and parliament can determine the scope of the prerogative (Alder, 2009: 310), in those powers relating to foreign affairs, the report (Ministry of Justice, 2009: Annex, 31) included such matters as the making of treaties.

15 Macarthys Ltd v. Smith [1979] I.C.R. 785, 789.

16 Garland v. British Rail [1983] 2 A.C. 751, 771.

$17 R$. (on the application of HS2 Action Alliance Limited) v. Secretary of State for Transport [2014] UKSC 3.

18 HS2 [2014] UKSC 3 [206]-[207]. 
Despite Dicey's assertion (Dicey, 1959: 424) that every act "which the executive government can lawfully do without authority of an Act of Parliament is done in virtue of this prerogative", Phillipson more recently has rather emphasised the fact that the ambiguities that surround the royal prerogative, including its definition and scope, as well as the roles of both parliament and the courts in checking its exercise, represent one of the central problems of the UK constitution (Phillipson, 2016: 1064).

In order to help clarify matters, Craig has outlined (Craig, P. P., 2017: 49-50) the three main stages of analysis that the courts use when considering the prerogative.

(a) Does a prerogative power exist? Usually this is not a problem (as mentioned above, such a power exists in relation to foreign affairs and the making of treaties). In any event, the court needs to determine whether or not a prerogative exists in the light of the existing historical evidence. When doing so the court may delineate or define more specifically the subject matter area in relation to which the prerogative exists;

(b) What is the extent of the prerogative? Again it is for the court to determine the types of limits or constraint it believes should, as a matter of principle, be placed on prerogative power, in the light of existing statutory provisions. In this work, the courts have found certain constraints on the prerogative, e.g., that it cannot alter the law of the land or affect rights ${ }^{19}$; and that it cannot be used where it would place statute law in abeyance or frustrate statutory rules ${ }^{20}$. Even these constraints can be contested both as to type and as to how they are to be applied in a particular case; and

(c) How is the prerogative exercised? The House of Lords in the GCHQ case $^{21}$ decided that the manner of exercise of prerogative discretionary power was reviewable by the courts in the same way as statutory discretionary power. In this sense, it was the subject matter, and not the source of the power, which was determinative.

\section{THE MILLER CASE}

In view of the uncertainty of the use of prerogative to secure withdrawal under art. $50 \mathrm{TEU}$, private citizens brought an action before the Divisional

\footnotetext{
19 Case of Proclamations (1611) 12 Co. Rep. 74.

20 Attorney General v. De Keyser's Royal Hotel Ltd [1920] A.C. 508.

21 Council of Civil Service Unions v. Minister for the Civil Service [1985] A.C. 374.
} 
Court (Queen's Bench Division) of the High Court of England and Wales seeking determination of the matter ${ }^{22}$.

The claimants submitted inter alia that: (i) the exercise of prerogative powers could not extend to acts that resulted in a change to domestic law; (ii) withdrawal from the EU Treaties would change domestic law; and (iii) therefore, the British government could not serve the withdrawal notice through exercise of its prerogative alone since such exercise had first to be authorised by an Act of Parliament.

The court (Lord Thomas LCJ, Sir Terence Etherton MR and Sales LJ) declared $^{23}$ that the government did not have power to give notice, without parliament's prior authority. On appeal, the Supreme Court upheld the decision of the lower court by a majority of $8-3^{24}$.

\subsection{Parliamentary sovereignty in Miller}

In Miller, Diceyan notions of parliamentary sovereignty received a strong, $21^{\text {st }}$-century reaffirmation ${ }^{25}$. Delivering the jointly-reasoned majority judgment, Lord Neuberger rejected any suggestion of a revolutionary nature for the Factortame decision ${ }^{26}$ :

Of course, consistently with the principle of Parliamentary sovereignty, this unprecedented state of affairs [i.e., the application of the principle of primacy of EU law] will only last so long as Parliament wishes: the 1972 Act can be repealed like any other statute. For that reason, we would not accept that the so-called fundamental rule of recognition (ie the fundamental rule by reference to which all other rules are validated) underlying UK laws has been varied by the 1972 Act or would be varied by its repeal.

In respect of parliamentary sovereignty and the clear foundations of EU law in the UK legal system, Lord Neuberger subsequently said ${ }^{27}$ that EU law enjoyed its automatic and overriding effect only by virtue of the ECA, and thus only while it remained in force. According to the majority, then, such

$22 R$. (on the application of Miller) v. Secretary of State for Exiting the European Union [2016] EWHC 2768 (Admin).

23 Miller [2016] EWHC 2768 (Admin) [77]-[111].

$24 R$. (on the application of Miller) v. Secretary of State for Exiting the European Union [2017] UKSC 5.

25 Miller [2017] UKSC 5 [43].

26 Miller [2017] UKSC 5 [60].

27 Miller [2017] UKSC 5 [61] 
point simply reflected the fact that the UK parliament was and remained sovereign: so, no new source of law could come into existence without parliamentary sanction - and without being susceptible to its being abrogated by parliament.

Lord Neuberger continued by noting that, because EU law had primacy by operation of the ECA, domestic legislation which was inconsistent with EU law was to that extent ineffective in law ${ }^{28}$ : "The principle of Parliamentary sovereignty $[\ldots]$ is $[\ldots]$ fundamental to the United Kingdom's constitutional arrangements, and EU law can only enjoy a status in domestic law which that principle allows. It will therefore have that status only for as long as the 1972 Act continues to apply, and that, of course, can only be a matter for Parliament".

This approach (Ewing, 2017: 714-715) is consistent with and develops similar views that the Supreme Court had expressed above in the HS2 case (though the majority position in Miller is much more explicit). Consequently, by repealing the ECA, parliament will eventually be asserting its sovereignty to reclaim a power it had, in fact, never surrendered.

\subsection{Exercise of prerogative power for EU withdrawal not permissible}

The issue in the case concerned two conflicting notions at the centre of the British constitution, as stated in Miller" ${ }^{29}$ (i) "ministers enjoy a power freely to enter into and to terminate treaties without recourse to Parliament"; and (ii) "ministers are not normally entitled to exercise any power they might otherwise have if it results in a change in UK domestic law, unless statute, i.e. an Act of parliament, so provides".

In Miller, while acknowledging that exercise of prerogative powers could not change national law, Lord Neuberger held that there were two categories of case where such an exercise could have domestic legal consequences and which would be the subject of control by the courts.

The first ${ }^{30}$ was where it was inherent in the prerogative power that its exercise would affect the legal rights or duties of others ${ }^{31}$. While the exercise of the prerogative power in such cases might affect individual rights, the

\footnotetext{
Miller [2017] UKSC 5 [67].

Miller [2017] UKSC 5 [5].

Miller [2017] UKSC 5 [52].

31 Council of Civil Service Unions v. Minister for the Civil Service [1985] A.C. 374; and Burmah Oil Co (Burma Trading) Ltd v. Lord Advocate [1965] A.C. 75.
} 
important point was that it did not change the law because the law had always authorised the exercise of the power.

The second category ${ }^{32}$ covered cases where the effect of an exercise of prerogative powers was to change the facts to which the law applied ${ }^{33}$. In such category, the exercise of the prerogative power altered the status of a person, thing or activity so that an existing rule of law came to apply to it. However, in such cases, the exercise had not created or changed the law, merely the extent of its application.

In considering the application of these two categories to the present case, the British government was proposing by prerogative to withdraw from the $\mathrm{EU}$ and it was clear that such withdrawal would have the effect not only of taking away important rights but also of dismantling an entire source of law (Ewing, 2017: 717. But see Craig, R., 2016; Mac Amhlaigh, 2017; and Poole, 2017). The latter contained a substantial body of rights, e.g., the rights to equal treatment, the protection of EU competition law, and rights derived from the four freedoms, as well as other rights, in particular those arising from directly applicable EU regulations, or rights arising directly under the EU Treaties, would cease to have effect upon withdrawal ${ }^{34}$. In addition, there would also be the loss of a right of access to the Court of Justice of the European Union $(\mathrm{CJEU})^{35}$. This was an important matter to which the majority referred for, although the government was proposing in the subsequent Withdrawal Bill to convert existing EU rights formally into British rights ${ }^{36}$ (discussed in section III.3.2), there would still be the loss of access to the CJEU for guidance on the interpretation of these rights and the loss of a possible uplift as a result $\mathrm{t}^{37}$.

Since it was clear that such opportunities for uplift would be lost after Brexit, with the probability of a divergence between EU law and UK EUderived law after Brexit, the majority in Miller acknowledged the fact that ${ }^{38}$ :

32 Miller [2017] UKSC 5 [53].

33 Joyce v. Director of Public Prosecutions [1946] A.C. 347; and Post Office v Estuary Radio Ltd [1968] 2 Q.B. 740.

34 Miller [2017] UKSC 5 [69]-[70].

35 Miller [2017] UKSC 5 [70].

${ }^{36}$ Miller [2017] UKSC 5 [70].

37 Miller [2017] UKSC 5 [34]. In fact, as Lord Neuberger remarked, there had been many cases where the CJEU had intervened on a wide range of issues to lift British law to meet obligations under a range of Directives.

38

Miller [2017] UKSC 5 [80]. 
Upon the United Kingdom's withdrawal from the European Union, EU law will cease to be a source of domestic law for the future (even if the Great Repeal Bill provides that some legal rules derived from it should remain in force or continue to apply to accrued rights and liabilities), decisions of the Court of Justice will (again depending on the precise terms of the Great Repeal Bill) be of no more than persuasive authority, and there will be no further references to that court from UK courts. Even those legal rules derived from EU law and transposed into UK law by domestic legislation will have a different status. They will no longer be paramount, but will be open to domestic repeal or amendment in ways that may be inconsistent with EU law.

Following on from the above, Lord Neuberger concluded the majority's argument against the government's use of the prerogative to leave the EU (and thus without parliamentary approval to do so $)^{39}$ :

While the consequential loss of a source of law is a fundamental legal change which justifies the conclusion that prerogative powers cannot be invoked to withdraw from the EU Treaties, the Divisional Court was also right to hold that changes in domestic rights acquired through that source [...] represent another, albeit related, ground for justifying that conclusion. Indeed, the consequences of withdrawal go further than affecting rights acquired pursuant to section 2 of the 1972 Act [...]. More centrally [...] section 2 of that Act envisages domestic law, and therefore rights of UK citizens, changing as EU law varies, but it does not envisage those rights changing as a result of ministers unilaterally deciding that the United Kingdom should withdraw from the EU Treaties.

The British government could not accordingly use the prerogative to withdraw from the EU since such withdrawal would change the law both because it would involve loss of a source of law and because of the impact on rights. In this situation, the majority of the Supreme Court dismissed the appeal and thus determined that the UK parliament would have to give prior approval to the British government's notification to withdraw from the EU. This prior approval was subsequently given through statute and so, pursuant to the European Union (Notification of Withdrawal) Act 2017, ${ }^{40}$ the government triggered the art. 50 TFEU process on 29 March 2017 by an official letter addressed to European Council President Donald Tusk (May, 2017b).

Having gone through this process of notification, one further issue needs to be considered: in the case that the UK were to change its mind (e.g., after a

39 Miller [2017] UKSC 5 [83].

40 European Union (Notification of Withdrawal) Act 2017, c. 9, section 1. 
general election, or a referendum on the results of the negotiations were voted down) (Gordon, 2016: 429), could the notification be withdrawn unilaterally (given that the original notification to withdraw was unilateral) or, if necessary, by mutual consent? Or is the notification of withdrawal irrevocable?

The point is still moot at this time (Łazowski, 2016). While the majority of academics favour the possibility for the UK to revoke its notification of withdrawal (Craig, P. P., 2016: 463-464; Eeckhout and Frantziou, 2017: 711-714; Sari, 2017: 458-459; Tridimas, 2016: 303), there are still some who argue that such notification is irrevocable (Ostendorf, 2017: 767-776). The latter group has already received support in their argument from three courts in the United Kingdom: the High Court of England and Wales in Miller, ${ }^{41}$ the High Court of Northern Ireland in $\mathrm{McCord}^{42}$, and the UK Supreme Court in Miller, in which latter case Lord Neuberger stated ${ }^{43}$ :

In these proceedings, it is common ground that notice under article 50(2) (which we shall call "Notice") cannot be given in qualified or conditional terms and that, once given, it cannot be withdrawn. Especially as it is the Secretary of State's case that, even if this common ground is mistaken, it would make no difference to the outcome of these proceedings, we are content to proceed on the basis that that is correct, without expressing any view of our own on either point. It follows from this that once the United Kingdom gives Notice, it will inevitably cease at a later date to be a member of the European Union and a party to the EU Treaties.

A further attempt in the matter - this time for judicial review on the issue of the unilateral revocability of art. $50 \mathrm{TEU}$ — was made by a group of members of the Scottish and European parliaments before the Outer House of the Court of Session in Edinburgh. Lord Doherty, in his Opinion in Wight$m a n^{44}$, ruled however that he was not satisfied that the application would have a real prospect of success and therefore refused permission to proceed. An appeal to the Inner House is expected to be made (The Herald, 2018).

Despite such judicial opinion, the European institutions have also entered into the debate, emphasising that while the notification is revocable, such revocation could not be unilateral. The European Parliament has posited that a hypothetical revocation should be some form of multilateral act and include conditions set by the remaining Member States (European Parliament, 2017: point L). The Commission also seems to maintain that a decision to

\footnotetext{
Miller [2016] EWHC 2768 (Admin) [10].

Re McCord [2016] NIQB 85 [23].

Miller [2017] UKSC 5 [26]. Emphasis supplied.

Wightman MSP and others for Judicial Review [2018] ScotsCS CSOH 8.
} 
revoke is feasible, albeit not unilaterally (European Commission, 2017). Nevertheless, as already noted (Sari, 2017: 473), it would ultimately be for the CJEU to provide an authoritative interpretation of art. $50 \mathrm{TEU}$ in order to finally resolve the debate.

\section{THE NATURE OF EU LAW BEFORE AND AFTER BREXIT}

\section{BACKGROUND}

The nature and position of EU law in the British constitutional system has already been discussed in relation to parliamentary sovereignty (section II.2.1 above). In this section, consideration will shortly be made to the radical new way that the UK Supreme Court in Miller envisaged EU law as well as what proposed effects the EU acquis is intended to have in the UK after Brexit day, through the operation of the European Union (Withdrawal) Bill.

\section{PRE-BREXIT: MILLER CASE AND THE NEW UNDERSTANDING OF EU LAW IN THE UK}

The previously regarded conceptualisation of EU law, stemming from Lord Denning in Macarthys v. Smith or Lord Bridge in Factortame (section II.2.1), was radically altered in Miller. Although Lord Neuberger for the majority recognised that EU law originated from the EU institutions and became effective in the UK through means of the $\mathrm{ECA}^{45}$, he continued ${ }^{46}$ :

But in a more fundamental sense and, we consider, a more realistic sense, where EU law applies in the United Kingdom, it is the EU institutions which are the relevant source of that law. The legislative institutions of the EU can create or abrogate rules of law which will then apply domestically, without the specific sanction of any UK institution... So long as that Act remains in force, the EU Treaties, EU legislation and the interpretations placed on these instruments by the Court of Justice are direct sources of UK law.

Thus the validity of EU law did not originate from the ECA (Khushal Murkens, 2017: 688): instead the effect of the ECA was to recognise EU $\operatorname{law}^{47}$ as "an entirely new, independent and overriding source of domestic law,

45 Miller [2017] UKSC 5 [61].

46 Miller [2017] UKSC 5 [61].

47 Miller [2017] UKSC 5 [80]. 
and the Court of Justice as a source of binding judicial decisions about its meaning". In this sense, the UK Supreme Court appears to have adopted the CJEU's understanding of EU law in Costa v. ENEL, viz. that ${ }^{48}$ : "The law stemming from the Treaty, an independent source of law, could not, because of its special and original nature, be overridden by domestic legal provisions". In so doing, the Supreme Court recognised that the loss of such a domestic source of law through withdrawal would effect ${ }^{49}$ "a fundamental change in the constitutional arrangements of the United Kingdom," which change could only occur through prior parliamentary authorisation.

\section{POST-BREXIT: EUROPEAN UNION (WITHDRAWAL) BILL}

The European Union (Withdrawal) Bill ("the Withdrawal Bill") was published on 13 July $2017^{50}$. Its purpose is to cut off the source of EU law in the UK by repealing the ECA on Brexit day and by returning to the UK parliament the sole competence to legislate over policy areas where such competence had previously been ceded to or shared with the $\mathrm{EU}^{51}$. The Bill provides for a complex mixture of constitutional change and legal continuity and extends to England and Wales, Scotland and Northern Ireland, having implications for the devolved governments of those nations.

By the time the Withdrawal Bill came before the House of Lords on 18 January 2018, the upper chamber had already indicated that the Bill as drafted was "constitutionally unacceptable" and promised to undertake to make amendments to it (House of Lords, 2018: Summary). Nevertheless, there are limits as to what the Lords can achieve: the ultimate legislative override of the House of Commons (Alder, 2009: 238-239) will keep any of these changes to no more than advice to reconsider the lower house's position on certain points ${ }^{52}$.

\subsection{The need to ensure legal certainty and continuity}

While the 2016 referendum for those advocating departure from the Union was all about "taking back control" of law-making from the EU, little

48 Judgement of the Court of 15 July 1964 Case 6/64 Flaminio Costa v. ENEL, 6/64, EU:C:1964:66, 594.

49 Miller [2017] UKSC 5 [78].

50 European Union (Withdrawal) Bill, version before the House of Lords, 18-1-2018: Retrieved from: https://goo.gl/z9gUAM (Withdrawal Bill).

51 Withdrawal Bill, clause 1.

52 The Withdrawal Bill's impact on the law-making powers of the devolved nations will be considered in section IV.4 below. 
thought seems to have been paid to the realities of the situation of withdrawing from the Union, without having addressed the enormous legal gaps that could open up were EU law to lose its force on Brexit.

As the reverse process of enlargement that sees the adoption of the Union's acquis by an acceding State (Tatham, 2009: 329-356), the process of withdrawal will ultimately see the gradual sloughing off of EU law from British statute books. The latter process is extremely complicated since there are many thousands of pieces of legislation ${ }^{53}$ that have come from the EU during more than 40 years of UK membership. The period now left to complete the process by the Brexit date, set at 11.00 p.m. GMT on 29 March $2019^{54}$, is such as to render any attempt during that time at "domesticating" all EU law — its adoption as law by the UK and possibly the devolved parliaments — as inconceivable.

It therefore becomes necessary to ensure that EU law in some way remains in effect after Brexit: legal certainty and continuity underlie any attempt to ensure the smooth and orderly transition (or return) to a sovereign domestic legal order. The need for such provision is one with which the UK is familiar throughout its decolonisation process where, in order to avoid a vacuum pending the creation of legal rules by the new (post-independence) legislature, laws in existence at the time of independence were "saved" in the UK statute granting the colonial territory independence (Corrin Care, 1997: 34). Needless to say, the decommissioning of the body of the acquis in the UK requires novel concepts in order to cope with the enormity of the process.

\subsection{Retained EU law}

The Bill creates a new category of domestic law called "retained EU law" 55 that will consist of all EU law in force on the day before Brexit and will continue to be, or form part of, domestic law by virtue of the (future)

53 While there is no single figure for how much EU law already forms part of UK law (and how much will therefore be converted by the Withdrawal Bill), according to EUR-Lex, the EU's legal database, there are currently over 12,000 EU regulations and over 6,000 EU directives in force. In addition, there have been around 7,900 UK statutory instruments that have implemented EU legislation and, out of 1,302 UK Acts between 1980 and 2009 (excluding those later repealed), 186 Acts (or 14.3\%) exhibited a degree of EU influence (Department for Exiting the European Union, 2017: point 11).

54 Withdrawal Bill, clause 14(1): thus, for most of the EU-27, 12.00 midnight CET on the same day.

55 Withdrawal Bill, clause 6(7). 
Withdrawal Act; it may accordingly be later amended, replaced or repealed by the UK parliament. This category of retained EU law contains the following elements:

(a) EU-derived domestic legislation ${ }^{56}$ : mostly EU directives under art. 288 TFEU previously harmonised by the UK into domestic law;

(b) EU direct legislation ${ }^{57}$ : mainly EU regulations and EU decisions under art. 288 TFEU as well as EU tertiary legislation under arts. 290 and 291 TFEU;

(c) Retained case law ${ }^{58}$ : comprising both (a) retained domestic case-law being any principles and decisions of a UK court or tribunal that had applied EU law before Brexit; and (b) retained European case-law being any principles and decisions of the CJEU as they have effect in EU law before Brexit;

(d) Retained general principles of EU law: covering all such principles as they have effect in EU law before Brexit. However ${ }^{59}$, there will be no post-Brexit right of action in domestic law based on a failure to comply with these general principles; and after Brexit, no court or tribunal (or other public authority) may disapply or annul any legal rule, or annul any conduct or otherwise decide that it is unlawful, because of its incompatibility with such general principles.

Despite the desire to ensure continuity, the Withdrawal Act will necessarily seek to remove certain laws and principles from UK law on Brexit day. Such matters that will not be saved or incorporated into the domestic legal system include:

(a) The principle of the supremacy of EU law ${ }^{60}$ : this will not apply to any domestic legal rule passed or made on or after Brexit day. However, it will continue to apply in so far as is relevant to the interpretation, disapplication or annulling of any legal rule passed or made before Brexit and may apply to post-Brexit modifications to pre-Brexit legal rules if the application of the principle is consistent with the intention of the modification.

\footnotetext{
56 Withdrawal Bill, clause 2.

57 Withdrawal Bill, clause 3.

58 Withdrawal Bill, clause 6(7)

59 Withdrawal Bill, Schedule 1, paragraph 3.

60 Withdrawal Bill, clause 5.
} 
(b) The Charter of Fundamental Rights: this ceases to be part of domestic law post Brexit. But this does not affect the post-Brexit retention in domestic law of any fundamental rights or principles which exist irrespective of the Charter (and references to the Charter in any case-law are, so far as necessary for this purpose, to be read as if they were references to any corresponding retained fundamental rights or principles). This means that the CJEU's case-by-case creation of a catalogue of fundamental rights will be retained as will its use of rights under the European Convention of Human Rights, European Social Charter, International Labour Organization Conventions, etc.

(c) Challenging the validity of EU retained legislation ${ }^{61}$ : there will be no post-Brexit right in domestic law to challenge any retained EU law on the basis that, immediately before exit day, an EU instrument was invalid (although domestic regulations may provide for such a challenge to be made against a UK public authority).

(d) Francovich ${ }^{62}$ : after Brexit, the rule on state liability in this case will cease to apply.

Lastly, while the Bill provides for a means to retain, for the time being, the corpus of EU law which applies to the UK pre-Brexit, domestic courts will, when interpreting retained EU law post-Brexit, no longer be bound by any CJEU rulings or principles laid down by it nor will they have the right to refer any matter to the CJEU under art. $267 \mathrm{TFEU}^{63}$. Interestingly ${ }^{64}$, although a domestic court or tribunal "need not have regard to anything done on or after exit day by the European Court, another EU entity or the EU", it may still do so "if it considers it appropriate to do so". National courts will eventually have to interpret these novel concepts under the Withdrawal Bill and to decide how they fit within the new UK constitutional framework.

In this respect, Lord Neuberger (interviewed before his retirement as President of the UK Supreme Court in 2017) had already indicated in respect of post-Brexit rulings of the CJEU (Coleman, 2017): "If the UK parliament says we should take into account decisions of the [CJEU] then we will do so. If it says we shouldn't then we won't. Basically we will do what the statute says". The "appropriateness" of a CJEU ruling, in the wording of the Withdrawal Bill, would require the court to take full responsibility for applying

\footnotetext{
61 Withdrawal Bill, Schedule 1, paragraph 1.

62 Withdrawal Bill, Schedule 1, paragraph 4.

63 Withdrawal Bill, clause 6(1).

64 Withdrawal Bill, clause 6(2).
} 
such ruling in the case before it post-Brexit: this is a responsibility that courts in the UK are extremely reluctant to assume. They would, in fact, prefer an express statutory obligation requiring them to use post-Brexit CJEU case-law in interpreting retained EU law.

\subsection{Henry VIII clauses}

One important issue that has arisen already in the process of debating the Withdrawal Bill in the House of Commons and will be subject to much discussion in the House of Lords (House of Lords, 2017: 201-206), is the British government's use of so-called "Henry VIII clauses."

Henry VIII clauses take their name from the Statute of Proclamations $1539^{65}$ which gave the King power to legislate by proclamation rather than needing to summon parliament in order to legislate. These days, such provisions in a statute are added in order to enable parliament to delegate to the government the necessary powers to repeal or amend such statute after it has become an Act of Parliament, without necessarily any further parliamentary scrutiny: such legislative changes are made by delegated or subordinate legislation (in the form of statutory instruments) (Alder, 2009: 144-145).

The delegated powers proposed under the Withdrawal Bill are very wide-reaching in nature. The main government justification for such an extensive grant of delegated legislative powers stems directly from the enormous body of the acquis already in existence in the UK. Through these delegated powers, the British government would have the power to amend, if certain conditions are met, all retained EU law, including retained EU law that had been implemented in the UK through primary legislation. One of the Bill's main powers is designed to enable the government to change retained EU law so as to ensure that it operates effectively outside the $\mathrm{EU}^{66}$. The powers proposed could also be used to change primary and secondary legislation that is not retained EU law, so long as the purpose of the change was to resolve a deficiency of retained $\mathrm{EU} \mathrm{law}^{67}$.

Although many changes would be technical in character, the delegated powers would enable the government to make substantive policy changes to retained EU law, e.g., by replacing redundant law with new rules and standards ${ }^{68}$

\footnotetext{
31 Hen. VIII, c. 8.

66 Withdrawal Bill, clause 7(1)(a).

67 Withdrawal Bill, clause 7(1)(b) and (2)-(5).

68 Withdrawal Bill, clause 7(2)(a)
} 
or creating new public authorities to take on functions formerly held by EU institutions ${ }^{69}$.

In this context, the House of Lords has already indicated its concerns in this respect (House of Lords, 2018: paragraphs 39-58). Granted it understood that the British government would require some Henry VIII powers in order to amend primary legislation to facilitate the UK's withdrawal from the EU, nevertheless it cautioned that they should not be granted lightly, and they had to come with commensurate safeguards and levels of scrutiny. As the Withdrawal Bill currently stands, the House has great concerns that the government has initiated a "power grab" under the guise of Brexit and has criticised the broad and open-ended nature of many of the delegated powers proposed by the government. For example, the House of Lords Select Committee on the Constitution proposed (House of Lords, 2018: paragraph 40): "The power of ministers to do what they consider 'appropriate' is subjective and inappropriately wide. We recommend that the Bill be amended [...] to provide that, while the power remains available when ministers consider it 'appropriate', they must demonstrate that there are 'good reasons' for its use and can show that the use of the power is a 'reasonable course of action'".

This would require the government to give explanations for the use of the power which could then be scrutinised by parliament and would additionally provide a meaningful benchmark against which such use of the power might be tested before the courts.

\section{BREXIT AND THE IMPACT ON DEVOLUTION}

\section{BACKGROUND}

Since the late 1990s, devolution has transformed the way in which the UK is run. Devolution essentially means the decentralisation of government and transfer of more powers from the central British parliament to the three devolved nations of Scotland, Wales and Northern Ireland. Confirmation of this new settlement was made through plebiscites in 1997 in Scotland and Wales, and in 1998 in the island of Ireland (including the Republic): this resulted in the creation of the Scottish parliament and assemblies for Wales and Northern Ireland (Alder, 2009: 346-363).

The main powers devolved commonly to the three nations include agriculture, education, environment and health while law-making powers in

69 Withdrawal Bill, clause 7(2)(b)-(e) and (6). 
other sectors have also been devolved to one or other nation. The British government ultimately remains responsible for national policy on all powers that have not been devolved and these include foreign affairs, defence, international relations, international treaties, currency, nationality, immigration and economic policy. The British parliament is technically still able to pass laws for any part of the UK but in practice only deals with devolved matters with the agreement of the devolved governments (Sewell Convention, see below in section IV.4).

\section{IMPACT ON THE UK DEVOLUTION SETTLEMENT IN GENERAL}

Without a doubt, Brexit will impact on the devolution settlement and may lead to some "rough weather" in political terms. This situation is further complicated by the fact that in the 2016 referendum (Electoral Commission, 2016) both Northern Ireland (55.8 \%) and Scotland (62 \%) voted by majorities to remain in the EU; and, while Wales voted to leave $(52.5 \%)$, the Welsh government and parliament are still largely in favour of remaining in the customs union and the single market.

Relations between the British government and those of the three devolved nations is governed by the Memorandum of Understanding (reissued in 2013), according to which a Joint Ministerial Committee (JMC) was established to provide "central co-ordination" of relations between the four governments (Memorandum of Understanding, 2013: paragraph 23). Plenary meetings of the JMC, chaired by the UK Prime Minister and attended by the First Ministers (and deputy First Minister of Northern Ireland), are held at least once a year. At the October 2016 JMC meeting, a Joint Ministerial Committee (EU Negotiations) - JMC (EN) - was established, to be chaired by the Secretary of State for Exiting the EU.

The terms of reference of the JMC (EN) (HM Government, 2016) underlined the four governments' intention to work together to: (i) discuss each of their requirements for the future relationship with the EU; (ii) seek to agree a UK approach to, and objectives for, the Brexit negotiations; (iii) provide oversight of these negotiations, to ensure (as far as possible) that outcomes agreed by all four governments were secured from the negotiations; and (iv) discuss issues stemming from the negotiation process which might impact upon or have consequences for any of the governments. Despite these intentions, the practice of the JMC (EN) has not borne out this collaborative ideal (House of Lords, 2017: 67-73): this may reflect divisions between the governments as to the need to remain in the EU customs union and/or single market as well as the fact that the Scottish and Welsh executives are made up of parties in opposition at Westminster while the executive in Northern 
Ireland is currently suspended, with its main loyalist party supporting the Conservative government in Westminster.

\section{DELAYING WITHDRAWAL?}

The first test of the relative power of the three devolved nations came in the $M c C o r d$ case $^{70}$ before the High Court in Belfast. The claimants maintained that devolution required the court to determine whether the provisions of the Northern Ireland Act $1998^{71}$ (NIA) (which had devolved power to that nation) required primary legislation, and the consent of the Northern Ireland Assembly and/or the people of Northern Ireland, before a withdrawal notice could be served by the UK government. Having held against the claimants, the High Court referred several questions to the UK Supreme Court which were decided together in the Miller case.

On the devolution issues, the Supreme Court unanimously held that the NIA did not require primary legislation or the aforementioned consent before the UK government could notify its withdrawal from the EU. According to Lord Neuberger ${ }^{72}$, the British parliament had passed the devolution statutes on the assumption that the UK would be an EU Member State but those statutes did not require the UK to remain a member. Moreover, through those statutes, relations with the EU and other foreign affairs matters were reserved rather to the (central) British government and parliament and not to the devolved institutions. Moreover, the NIA which gave the people of Northern Ireland the right to determine whether to remain part of the UK or to become part of a united Ireland, did not regulate any other change in the constitutional status of Northern Ireland.

In this case, then, the Supreme Court reaffirmed the position that the British government and parliament alone were able to submit the notification for withdrawal from the EU without the agreement of the devolved nations.

\section{AMENDING DEVOLVED LAWS AND REPATRIATION OF POWERS FROM BRUSSELS}

However, this is not the end of the matter as the UK will not be able to ignore the three nations when it comes to seeking to pass the Withdrawal Bill. The severity of a potential crisis stems in part from the fact that EU law was

70 Re McCord [2016] NIQB 85 [23].

71 Northern Ireland Act 1998, c. 47.

72 Miller [2017] UKSC 5 [129]-[130]. 
incorporated directly into the devolution statutes in Scotland ${ }^{73}$, Wales ${ }^{74}$ and Northern Ireland ${ }^{75}$. At the present time, these devolved legislatures therefore cannot legislate contrary to EU law. The Withdrawal Bill changes this restriction and instead provides, post-Brexit, that those legislatures will not be able to legislate contrary to retained $\mathrm{EU}_{\text {law }}{ }^{76}$.

In practical terms, this may not amount to much of a change with what currently happens. Yet the basis of the restrictions, in constitutional terms, will be altered: while they are now based on the fact that the three devolved legislatures are all part of an EU Member State, the Withdrawal Bill provides that, post-Brexit, the restrictions would rather only be based on a British statute.

Without this change in the Withdrawal Bill, once the UK were no longer a Member State, the devolved legislatures would be able to legislate in areas currently covered by EU law that were within their devolved competence, such as agriculture or the environment. Seen in this way, the Bill effectively re-reserves to the UK parliament these areas of competence, within competences that have otherwise been devolved and without any guarantee that the British parliament will actually devolve them once more to the three nations. Thus Scotland, Wales and Northern Ireland are conscious of the potential loss of law-making under a disguised repatriation to the UK parliament of legislative powers from the EU which are then not passed back on to the devolved nations' assemblies.

Consequently, although the UK parliament will repeal the ECA, such repeal will not terminate the domestic incorporation of EU law in the devolved nations. It will still be necessary to have the agreement of each devolved legislature to amend the relevant parts of their own foundational devolution legislation at the same time.

And such agreement from the devolved legislatures would be absolutely essential since, although the UK parliament can still amend those three devolution Acts, the British government has stated (under the so-called the Sewel Convention ${ }^{77}$ ) that it would not normally pass a law on a devolved matter

73 Section 29(2)(d) of the Scotland Act 1998, c. 46, provides that Acts of the Scottish Parliament that are incompatible with EU law are "not law."

74 Section 108(6) Government of Wales Act 2006, c. 32, states that any act of the Welsh Assembly incompatible with EU law, falls outside its competence.

75 Section 24 of the Northern Ireland Act 1998, c. 47, prohibits any legislation contrary to EU law.

76 Withdrawal Bill, clause 11.

77 The Sewel Convention is named after Lord Sewel, who was the Scotland Office Minister in the House of Lords responsible for the conduct through that House of the bill that later became the Scotland Act 1998. During the second reading debate, he said: 
without the consent of the devolved legislature in question, neither would it seek to amend the powers of the devolved legislatures or of the devolved executives without their prior consent.

The Sewel Convention was adopted as a means of establishing cooperative relationships between the British parliament and the devolved institutions. As a convention (Barber, 2009), it is a binding (non-legal) rule of constitutional behaviour, mainly dealing with the relationships between the different branches of government and not directly enforceable before the courts $^{78}$ : its breach, like that of any constitutional convention, attracts political consequences but no legal penalty imposed by a court of law (Khusal Murkens, 2017: 691). Thus the Supreme Court in Miller noted ${ }^{79}$ that the Sewel Convention was "a statement of political intent and [...] did not create legal obligations". This convention has now been incorporated into legislation for Scotland and Wales ${ }^{80}$, though not for Northern Ireland: nevertheless this legislative basis had no discernible effect on the effect of the convention itself according to the Supreme Court ${ }^{81}$ : "The purpose of the legislative recognition of the convention was to entrench it [i.e., give it greater political weight] as a convention".

Under the terms of the Sewel Convention, then, all Brexit-related amendments to the devolved legislation will thus require a legislative consent motion to be passed by the Scottish parliament, the Welsh assembly or the Northern Ireland assembly, in which the relevant devolved legislature agrees that the British parliament may pass legislation on a devolved issue over which the devolved body has regular legislative authority.

However, the heads of two of the devolved governments announced their intention not to grant such consent motions (Sturgeon and Jones, 2017). While the UK parliament could still legally pass the relevant legislation repatriating powers from Brussels as EU affairs (and is now prepared to do that: Carrell, 2018b), the political fall-out from doing so would likely strengthen

"As happened in Northern Ireland earlier in the century, we would expect a convention to be established that Westminster would not normally legislate with regard to devolved matters in Scotland without the consent of the Scottish parliament”. See HL Debates, volume no. 592, part no. 191, 21 July 1998, column 791.

78 Regardless of this, the judiciary have acknowledged conventions in a court of law: Attorney-General v. Jonathan Cape Ltd. [1975] 3 All E.R. 48.

79 Miller [2017] UKSC 5 [139].

80 Scotland Act 2016, c. 11, section 2 inserted sub-section (8) into section 28 of the Scotland Act 1998, c. 46; and Wales Act 2017, c. 4, section 2 inserted sub-section (6) into section 107 of the Government of Wales Act 2006, c. 32.

81 Miller [2017] UKSC 5 [149]. 
the hand of the Scottish nationalists (Young, 2017: 288). Any such action by the UK authorities would be supported by Miller: the majority noted that the Sewel Convention had an important role in facilitating harmonious relationships between the UK parliament and the devolved legislatures ${ }^{82}$ but since it created no legal obligations, despite its statutory form in those two nations, "the policing of its scope and the manner of its operation does not lie within the constitutional remit of the judiciary, which is to protect the rule of law".

The Miller decision on this point was immediately seized upon by Scottish First Minister Sturgeon as another ground for seeking an independent future (Sturgeon, 2017a): "Scotland's voice is simply not being heard or listened to within the UK. The claims about Scotland being an equal partner are being exposed as nothing more than empty rhetoric and the very foundations of the devolution settlement that are supposed to protect our interests - such as the statutory embedding of the Sewel Convention — are being shown to be worthless".

The First Ministers of Scotland and Wales have recently adopted a different tactic (Carrell, 2018a) and intend to introduce emergency bills designed to sidestep the UK parliament in the event of failing to make an agreement with Westminster on repatriation of legislative powers from Brussels, by taking direct control over the repatriation of significant EU legislation into Scottish or Welsh law. Such emergency bills, the First Ministers contend, would grant their devolved administrations the necessary powers in case they and the UK government fail to agree a deal on transferring and sharing up to $111 \mathrm{EU}$ powers over areas such as farming, fisheries, environment protection, justice and food labelling which are currently controlled by devolved governments. In response, the UK government has already threatened legal action before the Supreme Court.

The consequences of Brexit will therefore require the agreement of the three devolved legislatures in their field of competences: failure to achieve this would not necessarily halt legal preparations for Brexit as it remains constitutionally and legally possible for the British parliament to override the devolved legislatures ${ }^{83}$. Nevertheless, the political fall-out would be severe and would

Miller [2017] UKSC 5 [151].

83 Section 5 of the NIA empowers the Northern Ireland Assembly to make laws, but subsection (6) states that: "This section does not affect the power of the Parliament of the United Kingdom to make laws for Northern Ireland". Section 28(7) of the Scotland Act 1998 provides that the section empowering the Scottish Parliament to make laws "does not affect the power of the Parliament of the United Kingdom to make laws for Scotland". A substantially identical provision is made for Wales in section 107(5) of the Government of Wales Act 2006. 
probably see further legal and constitutional consideration of the operation of the Sewel Convention, especially in its legislated form in Scotland and Wales, as potentially giving rise to a legally enforceable obligation despite the opinion of the UK Supreme Court in Miller ${ }^{84}$. Indeed, part of Scotland's potential refusal of a consent motion is related to its own understanding of sovereignty.

\section{BREXIT AND NORTHERN IRELAND}

\section{BACKGROUND}

The putative impact on the island of Ireland of the UK's exit from the $\mathrm{EU}$ is serious and has the very real potential to undermine the very basis of the Northern Irish peace process, bringing into question the viability of devolved government there with all its attendant consequences (Phinnemore et al., 2015). In addition, considering the vital importance that Ireland (i.e., the Republic of Ireland as opposed to the island itself) attaches to this issue, the whole question of relations between the North and the South, especially in the face of a feared introduction of a hard border between both parts, was one of the three topics included in the first phase of negotiations.

\section{FREE MOVEMENT OF PERSONS AND GOODS}

The introduction, post-Brexit, of a hard (international/EU external) border running through the island of Ireland would be quite unprecedented for the island as a whole, at least in recent times.

Although Ireland separated from the UK in the 1920s, it nonetheless enjoys a rather unique relationship with its much larger neighbour. Section 2(1) of the Ireland Act $1949^{85}$ declared that, even though Ireland (when it became a republic) was no longer a British dominion, it would not be treated as a "foreign country" for the purposes of British law. For example, this allows Irish citizens to stand and vote in UK parliamentary elections.

Moreover, except for a period during and in the years after the Second World War, neither Ireland nor the UK has placed restrictions on travel between each other for citizens resident in each other's states since Irish independence. Together with the Crown Dependencies of the Channel Islands and the Isle of Man, they form the Common Travel Area (CTA) (Ryan,

84 Miller [2017] UKSC 5 [145]-[151].

85 Ireland Act 1949, 12, 13 \& 14 Geo. VI, c. 41. 
2001). The CTA is not founded on any formal agreement between Ireland and the United Kingdom or provided for in any legislation: rather, it is an informal arrangement between the states. When the Schengen Area Agreement was incorporated into the EU through the 1997 Treaty of Amsterdam, the first formal recognition of the CTA was made by an annexed Protocol ${ }^{86}$ that exempted Ireland and the UK from their obligations to join Schengen.

Originally initiated in 1923 on Irish independence, the CTA was reconfirmed in a revised version in 1952. In 2011, the first public agreement between the British and Irish governments (Green and Shatter, 2011) concerning the maintenance of the CTA was published under which they agreed reciprocal visa arrangements; measures to increase the security of the external CTA border; and to share immigration data between the two countries' immigration authorities.

What then will happen to the CTA between the two islands when the UK exits the EU? The 2015 Report of the Irish Parliamentary Joint Committee considered that the provisions of the Protocol exempting both states from applying Schengen "appear to imply that if the UK was no longer a member state of the EU, the Protocol would become redundant and by extension, the legal basis in EU law for the CTA would be questionable. This will have implications for both countries, notwithstanding their intentions" (Houses of the Oireachtas, 2015: 30). In order to maintain the status quo, post-Brexit, the 2015 Report proposed that a "mini Schengen" arrangement, based on the existing concept, might be the best option for the UK and Ireland to continue the CTA.

While free passage of people between north and south of the island has been the norm since 1923, free movement of goods dates back more recently to 1993 with the coming into force of the single market of the EU and the removal of physical customs controls between Member States. Although the Anglo-Irish Free Trade Agreement 1965 had provided for reduction and elimination of import duties on industrial and some agricultural products (Fitzgerald, 2001: 237-302), it was membership of the EEC in 1973 that led to the opening up of trade between the two States on becoming members of the customs union and ultimately of the internal market.

The amount of trade between the UK (especially Northern Ireland) and Ireland and its importance for the economies on both sides of the border cannot be understated. In this respect, the then heads of the Northern Ireland Executive, the then First Minister of Northern Ireland, Democratic Unionist

86 Art. 2 of Protocol No. 20 to the Treaty on European Union and the Treaty on the Functioning of the European Union. 
Party (DUP) Leader Arlene Foster, and the then deputy First Minister, Martin McGuinness of Sinn Féin (Irish nationalist party) had already sent a joint letter (Foster and McGuiness, 2016) to Prime Minister May in August 2016. They reiterated their "full commitment to achieving the best possible outcome for the people of Northern Ireland" and, regarding the land border, they highlighted the need to ensure that the movement of people, goods and services was not impeded; criminal justice and crime-fighting were not compromised; and an incentive was not thereby provided for those who wished to undermine the peace process. Both ministers further emphasised the need to retain both business competitiveness and, as possible, the ease of trade with EU Member States and access to labour. While the British and Irish governments at that time endorsed the concept of a "frictionless" border (BBC, 2017), its practical details have so far proved elusive in pinning down (Gleeson, 2017).

The discussion of the impact of Brexit on the Irish border question assumed even more importance when British Prime Minister May announced in her Lancaster House speech, in January 2017 (May, 2017a) that the UK would exit the EU customs union and the single market (rather than, e.g., seeking an EEA-style membership), the implications for the population of the whole island of Ireland became increasingly starker.

Promoting the position of Northern Ireland during the Brexit negotiations has become even more complicated since its Executive collapsed in early 2017, due to internal political difficulties, and by the fact that, following Prime Minister May's loss of an absolute majority in the June 2017 general election, the minority Conservative government has been kept in power by DUP members of the Westminster parliament.

\section{BELFAST AGREEMENT}

The importance of the EU in the evolution of relations between the UK and the Ireland has been invaluable. Common EU membership has facilitated the development of improved relations between the two States, as they worked together to resolve the conflict in Northern Ireland.

The product of that resolution is the Belfast (Good Friday) Agreement (Reynolds, 1999), an international treaty that includes many provisions concerning EU law. The status of the UK and Ireland as EU Member States is woven into the fabric of the Agreement: it provides for the establishment of a Northern Ireland Executive and Northern Ireland Assembly, as well as 
enshrining "North-South" and "East-West" co-operation. In addition, it has effected constitutional changes and established cross-border bodies ${ }^{87}$.

Without firm guarantees from the UK and the EU-27, Brexit might lead to an unravelling of the Belfast Agreement and undo much of what has been achieved in the last two decades in UK-Irish relations, undermining the operation of the relevant institutions established under the Agreement. While some have noted that the Agreement will merely need to be purged of references to the EU which will become redundant (Tonge, 2016: 339-340) something that, as it is a bilateral international treaty, might be achieved by an exchange of notes or a memorandum of understanding between the Irish and British governments - there are other aspects which need bolstering. One of these issues concerns the presence of the European Convention of Human Rights in the Agreement (Tonge, 2016: 339-340): with the UK's withdrawal from the EU whose membership requires states to adhere to the Convention, some fear that that withdrawal will undermine the UK's commitment to the Convention. The governing Conservative Party has previously noted it intention to take the UK out of the Convention (Asthana and Mason, 2016) with the resultant existential threat to the continuation of the operation of the Agreement.

\section{PROPOSED SOLUTIONS}

Considering the above, what solutions have been proposed? Both the $\mathrm{UK}$ and the EU affirmed at the end of the first phase of Brexit negotiations ${ }^{88}$ that the achievements, benefits and commitments of the peace process would remain of paramount importance to peace, stability and reconciliation and that the 1998 Belfast Agreement and its practical application had to be protected. In particular, the negotiating parties recognised the need to respect the provisions of the 1998 Agreement regarding the constitutional status of Northern Ireland and the principle of consent and that any commitments by the EU and the UK were and had to remain fully consistent with these provisions.

87 The institutions created between Northern Ireland and the Republic of Ireland are the North/South Ministerial Council, the North/South Inter-Parliamentary Association and the North/South Consultative Forum; while the institutions created between the islands of Ireland and Great Britain (as well the Crown Dependencies) are the British-Irish Intergovernmental Conference, the British-Irish Council and an expanded British-Irish Interparliamentary Body.

Joint Report, 2017: points 42-44. 
The UK for its part recalled its commitments ${ }^{89}$ : (a) to protecting the operation of the 1998 Agreement, including its subsequent implementation agreements and arrangements; (b) to the effective operation of each of the institutions and bodies established under the foregoing agreements and arrangements that underlie North-South co-operation; and (c) to the avoidance of a hard border, including any physical infrastructure or related checks and controls.

Any future arrangements would have to be compatible with these overarching requirements. However, the UK agreed that, in the absence of agreed solutions, it would": (a) "maintain full alignment with those rules of the Internal Market and the Customs Union which, now or in the future, support North-South cooperation, the all-island economy and the protection of the 1998 Agreement"; and (b) "ensure that no new regulatory barriers develop between Northern Ireland and the rest of the United Kingdom, unless, consistent with the 1998 Agreement, the Northern Ireland Executive and Assembly agree that distinct arrangements are appropriate for Northern Ireland". At the same time, the UK would continue to ensure the same unfettered access for Northern Ireland's businesses to the whole of the UK internal market.

Lastly, the CTA would continue to operate without affecting Ireland's obligations under EU law, in particular with respect to free movement for EU citizens; the birthright of the people of Northern Ireland (enshrined in the 1998 Agreement) to choose to be Irish or British or both and be accepted as such would be respected and those who were (also) Irish citizens would continue to enjoy rights as EU citizens, including where they resided in Northern Ireland; and the UK committed itself that no diminution of rights would be caused by Brexit, including in the area of protection against forms of discrimination enshrined in EU law and the related work of the institutions and bodies, under the 1998 Agreement, in upholding human rights and equality standards ${ }^{91}$.

Although the negotiating parties seemed to have reached an understanding on Northern Ireland, there is no clear explanation of how - in practical terms - they will square the circle of the UK's leaving the customs union and the internal market while maintaining a soft external border between the North and the South of the island. Put simply, it could be argued that the maintenance of "full alignment" with the internal market and customs union of the EU and the need to ensure "no new regulatory barriers" to develop

89 Joint Report, 2017: points 48-49.

90 Joint Report, 2017: points 49-50.

91 Joint Report, 2017: points 52-54. 
between Northern Ireland and the rest of the UK, might allow the North to act as some latter-day Trojan horse for "BINO," i.e., Brexit In Name Only. It is hard to be able to conceive of the EU allowing such a situation to exist on internal trade even with possible examples of Andorra or San Marino, or even Ceuta and Melilla, as precedents of some sort.

This view has been recently confirmed by the EU in its Draft Withdrawal Agreement published at the end of February 2018 (European Commission, 2018), that provides in art. 3 of the Protocol on Ireland/Northern Ireland: "A common regulatory area comprising the Union and the United Kingdom in respect of Northern Ireland is hereby established. The common regulatory area shall constitute an area without internal borders in which the free movement of goods is ensured and North-South cooperation protected in accordance with this Chapter".

In effect, Northern Ireland would remain in the customs union ${ }^{92}$ and, to some extent, the single market after Brexit in order to avoid a hard border: implicit in this idea is the fact that there would have to be controls on goods at airports and ports of entry into the island of Ireland from Great Britain: for critics, this would be tantamount to moving the "border" to the Irish Sea and so effectively dividing the UK although EU chief negotiator, Michel Barnier, has sought to downplay this idea (Boffey and Rankin, 2018).

\section{CONCLUSION}

Prior warnings of the centrifugal constitutional forces that would be unleashed with a vote in favour of Brexit (Douglas-Scott, 2016; Tatham, 2015) largely went unheeded. The "red lines" of Prime Minister May (2017a) of leaving the customs union, single market and jurisdiction of the CJEU have now returned to haunt her in the form of the Draft Withdrawal Agreement provisions in respect of Northern Ireland: both May (Asthana et al., 2018) and DUP leader Arlene Foster (Boffey, 2018) regard the province's continued membership of the customs union and partially of the single market - ostensibly in order to maintain the previously promised "frictionless" border (BBC, 2017) - as a direct attack on the integrity of the UK.

The idea of trying to "square the circle" of no hard border between the North and South of Ireland with the UK government's red lines was always going to prove to be an improbable call, all the more so with its potential for

92 Art. 4(2) of the Protocol on Ireland/Northern Ireland to the Draft Withdrawal Agreement. 
undermining the real gains over the last 20 years or so with the Belfast Agreement in Northern Ireland. The irresolvability of the border issue might, in the long term, give rise to two conflicting scenarios: on the one hand, by aligning its trade more closely with the south of the island, the province's continuing status within the UK could start to be called into question and ultimately promote calls for a referendum to unite with the Republic; on the other hand, it could prove to be the main justification for the UK to reclaim EU membership as argued by Belgian MEP Philippe Lamberts. If at least part of the UK (Northern Ireland) is bound to be kept in the customs union and (partially) single market because of the Belfast Agreement, the choice becomes stark: either the UK renounces the Agreement and then leaves the single market and customs union or it remains inside (or rejoins) the EU (Colson, 2018).

Even absent the issue of Northern Ireland, the Brexit process has already thrown up a range of other constitutional problems: in Miller, the UK Supreme Court took action to defend parliamentary sovereignty against an unjustifiable exercise of prerogative powers (Young, 2017: 286) while apparently failing to respect the new constitutional settlement created under devolution. Such a formally legalistic rejection of the devolved governments' positions will embolden those, particularly in Scotland, to find whatever legal means necessary to ensure that the repatriation of powers from Brussels does not amount to a usurpation of power by Westminster by a UK legislative override of the Sewel Convention but rather a confirmation of the devolution settlement.

In this respect, the First Minister has previously set out principles upon which Scotland would support the Brexit withdrawal agreement: the basic position of the SNP and most members of the Scottish parliament are for the UK to remain in the customs union and the single market (Sturgeon, 2017b). This argument has, in fact, been bolstered by the possibility of Northern Ireland remaining both in the UK and in the EU customs union (and partially in the single market); if this were to be finally confirmed, then the Scottish government would undoubtedly claim no less for their nation on grounds of equality being the other UK nation that voted by a majority to remain in the EU (Boffey et al., 2018).

Another attempted "power grab" is also being challenged, this time in the UK parliament. The British government's determination to use "Henry VIII clauses," in order to oust parliamentary scrutiny from large areas of the Brexit process represents for many parliamentarians a covert bid by the executive for an unconstitutional assumption of power at their expense. In the end, there will have to be a compromise: some parliamentary oversight, by means of each chamber's Brexit committee acting as a co-ordinator, should be introduced so that "nationalising" retained EU law would not escape scrutiny and 
review by parliamentarians and thereby ensure the British government would be held to account.

Lastly, some further guidance for the courts in dealing with the issue of CJEU interpretations of retained EU law after Brexit, both during the proposed transition or implementation period and beyond. In this scenario, the Agreement on the European Economic Area (EEA) provides an interesting example of maintaining legal homogeneity between the EU and the EFTA EEA states of Iceland, Liechtenstein and Norway. According to the Agreement ${ }^{93}$, the EFTA Court is supposed: (a) to interpret provisions of that Agreement that are identical in substance to the corresponding TFEU ones in conformity with the relevant rulings of the CJEU rendered before its signature on 2 May 1992; and (b) to pay "due account" to relevant CJEU rulings after that date. Since the EFTA Court recognised ${ }^{94}$ that the establishment of a dynamic and homogeneous market was inherent in the general objective of the EEA Agreement, it took the view that EEA law might be dynamically interpreted if this were necessary in order to achieve judicial homogeneity ${ }^{95}$. In practice, then, the EFTA Court does not distinguish between pre- and post-May 1992 CJEU case-law, thereby respecting it in its entirety (Skouris, 2005: 124-125) and applying it directly without temporal discrimination in cases before it. By following this precedent, the UK could provide a more secure and express basis in the Withdrawal Bill for domestic courts to apply relevant CJEU caselaw, post-Brexit, in order to interpret the relevant EU retained law. In fact, membership of the EFTA side of the EEA and the possibility of docking into the EFTA Court itself has even been promoted as a suitable alternative to the CJEU in order to respect one of the "red lines" (Baudenbacher, 2016).

\section{Bibliography}

Alder, J. (2009). Constitutional and Administrative Law. Basingstoke: Palgrave Macmillan.

Armstrong, K. A. (2017). Brexit Time: Leaving the EU. Why, How and When? Cambridge: Cambridge University Press. Availableat: https://doi.org/10.1017/9781108233385.

93 Agreement on the European Economic Area of 2 May 1992 (OJ L 1, 30 January 1994, p. 3), art. 6; read with Agreement between the EFTA States on the Establishment of a Surveillance Authority and a Court of Justice of 2 May 1992 (OJ L 344, 31 January 1994 , p. 3), art. 3(2).

94 Case E-4/01 Karl K. Karlsson hf. v. The Icelandic State [2002] EFTA Ct. Rep. 240.

95 Case E-4/04 Pedicel AS v. Sosial-og helsedirektoratet (Directorate for Health and Social Affairs) [2005] EFTA Ct. Rep. 1. 
Asthana, A. and Mason, R. (2016). UK must leave European convention on human rights, says Theresa May. The Guardian, 25-4-2016. Retrieved from: https:// goo.gl/zyNwhg.

— Elgot, J. and Perkins, A. (2018). Theresa May "will refuse Brexit deal that threatens UK integrity”. The Guardian, 27-2-2018. Retrieved from: https:// goo.gl/ATAc3c.

BBC (2017). Theresa May wants "frictionless" Irish border. BBC News, 29-3-2017. Retrieved from: https://goo.gl/AWqA74.

Barber, N. W. (2009). Law and Constitutional Conventions. Law Quarterly Review, 125 (1), 294-309.

Baudenbacher, C. (2016). After Brexit: Is the EEA an option for the United Kingdom? 42nd Annual Lecture of the Centre for European Law, King's College, London, 13-10-2016. Retrieved from: https://goo.gl/JrHKrs.

Birkinshaw, P. J. and Biondi, A. (eds.) (2016). Britain Alone! The Implications and Consequences of United Kingdom Exit from the EU. Alphen aan den Rijn: Kluwer Law International.

Boffey, D. (2018). EU plan to avoid hard Irish border unacceptable, says Arlene Foster. The Guardian, 6-3-2018. Retrieved from: https://goo.gl/YN88FA.

_ and Rankin, J. (2018). EU publishes plan to keep Northern Ireland in customs union. The Guardian, 28-2-2018. Retrieved from: https:/goo.gl/YkJWLv.

,O'Carroll, L. and Asthana, A. (2018). Brexit plan to keep Northern Ireland in customs union triggers row. The Guardian, 9-2-2018. Retrieved from: https:// goo.gl/eZXk6i.

Bradley, A. W., Ewing, K. and Knight, C. (2014). Constitutional and Administrative Law. London: Pearson.

Carrell, S. (2018a). UK government to fight Scottish bid for Brexit emergency powers. The Guardian, 1-3-2018. Retrieved from: https://goo.gl/8NdFbU.

- (2018b). UK ministers could push on with Brexit devolution plans despite opposition. The Guardian, 8-3-2018. Retrieved from: https://goo.gl/a9m6dG.

Castellà Andreu, J. M. (2016). El Referéndum sobre el Brexit: una historia inacabada. Revista de Derecho Político, 97, 297-334. Available at: https://doi.org/10.5944/ rdp.97.2016.17626.

Coleman, C. (2017). UK judges need clarity after Brexit. Lord Neuberger. BBC News, 8-8-2017. Retrieved from: https://goo.gl/X6928C.

Colson, T. (2018). This leading EU politician explains why Britain is likely to rejoin after Brexit. Business Insider, 7-3-2018. Retrieved from: https://goo.gl/FBc4uw.

Corrin Care, J. (1997). Colonial legacies? A study of received and adopted legislation applying in the University of the South Pacific region. Journal of Pacific Studies, 21, 33-59.

Craig, P. P. (2016). Brexit: A Drama in Six Acts. European Law Review, 41 (4), $447-$ 468. Available at: https://doi.org/10.1111/1468-2230.12229.

- (2017). Miller, structural constitutional review and the limits of prerogative power. Public Law, November Supplement (Brexit Special Extra Issue), 62, 48-72. 
Craig, R. (2016). Casting Aside Clanking Medieval Chains: Prerogative, Statute and Art. 50 after the EU Referendum. Modern Law Review, 79 (6), 1019-1089.

Del Valle-Gálvez, A. (2016-2017). Brexit Negotiations and Gibraltar: Time for a "Modus Vivendi"? Cuadernos de Gibraltar. Gibraltar Reports, 2, 19-26.

Department for Exiting the European Union. (2017). European Union (Withdrawal) Bill, Impact Assessment, 12-7-2017. Retrieved from: https://goo.gl/udjiKs.

Dicey, A. V. (1959). Introduction to the Study of the Law of the Constitution. London: Macmillan.

Douglas-Scott, S. (2016). Brexit, Article 50 and the Contested British Constitution. Modern Law Review, 79 (6) 1019-1040. Available at: https://doi. org/10.1111/1468-2230.12228.

Eeckhout, P. and Frantziou, E. (2017). Brexit and Article 50 TEU: A constitutionalist reading. Common Market Law Review, 54 (3), 695-734.

El Cronista del Estado Social y Democrático de Derecho. (2016). Special Issue on Brexit, 64

Electoral Commission. (2016). EU referendum results. Retrieved from: https://goo. $\mathrm{gl} / \mathrm{Td}$ sy $7 \mathrm{~h}$.

European Commission. (2017). Fact sheet on "The State of play of Article 50 negotiations with the United Kingdom," 12-7-2017. Retrieved from: https://goo. $\mathrm{gl} / \mathrm{bBNVZT}$.

(2018). Draft Withdrawal Agreement on the withdrawal of the United Kingdom of Great Britain and Northern Ireland from the European Union and the European Atomic Energy Community. TF50 (2018) 33, Brussels, 28-2-2018. Retrieved from: https://goo.gl/UUJtrf.

European Council. (2017). Guidelines, EUCO XT 20011/17, 15-12-2017. Retrieved from: https://goo.gl/Pe2zMd.

European Parliament. (2017). Resolution on negotiations with the United Kingdom following its notification that it intends to withdraw from the European Union, 5-4-2017. Retrieved from: https://goo.gl/Pe2zMd.

Ewing, K. (2017). Brexit and Parliamentary Sovereignty. Modern Law Review, 80 (4), 711-726. Available at: https://doi.org/10.1111/1468-2230.12281.

Feldman, D. (2017). Pulling a trigger or starting a journey? Brexit in the Supreme Court. Cambridge Law Journal, 76 (2), 217-233. Available at: https://doi. org/10.1017/S0008197317000435.

Fitzgerald, M. (2001). Protectionism to liberalisation: Ireland and the EEC, 1957 to 1966. Aldershot: Ashgate.

Foster, A. and McGuiness, M. (2016). Letter to the Prime Minister, the Rt Hon Theresa May MP from the First Minister and deputy First Minister of the Northern Ireland Executive, 10-8-2016. Retrieved from: https://goo.gl/HMy9Gt.

Gleeson, C. (2017). "Talk of 'frictionless Border' post-Brexit a fairy tale”, says Pascal Lamy. The Irish Times, 27-10-2017. Retrieved from: https://goo.gl/nM4xFs.

Gordon, M. (2016). Brexit: A challenge for the UK constitution, of the UK constitution? European Constitutional Law Review, 12 (3), 409-444. Available at: https://doi.org/10.1017/S1574019616000341. 
Green, D. and Shatter, A. (2011). Joint Statement by Mr. Damian Green, Minister of State for Immigration, the United Kingdom's Home Department and Mr. Alan Shatter, Minister for Justice and Equality, Ireland's Department of Justice and Equality regarding Co-operation on Measures to Secure the External Common Travel Area Border, 20-12-2011. Retrieved from: https:/goo.gl/UU1Wze.

Hillman, J. A. and Horlick, G. (eds.) (2017). Legal Aspects of Brexit: Implications of the United Kingdom's Decision to Withdraw from the European Union. Washington, D.C.: Institute of International Economic Law.

HM Government. (2016). Joint Ministerial Committee communiqué, 24-10-2016. Retrieved from: https://goo.gl/KyhCqq.

House of Lords. (2017). European Union Committee, Brexit: devolution, 4th Report of Session 2017-19, HL Paper 9, 19-7-2017. Retrieved from: https://goo. $\mathrm{gl} / \mathrm{CG} 1 \mathrm{PM}$.

- (2018). Select Committee on the Constitution, European Union (Withdrawal) Bill, 9th Report of Session 2017-19, HL Paper 69, 29-1-2018. Retrieved from: https://goo.gl/4d1Fbk.

Houses of the Oireachtas. (2015). Joint Committee on European Union Affairs, UK/ EU Future Relationship: Implications for Ireland, June 2015. Retrieved from: https://goo.gl/BPjL33.

Joint Report. (2017). Joint Report from the negotiators of the European Union and the United Kingdom Government on progress during phase 1 of negotiations under Article 50 TEU on the United Kingdom's orderly withdrawal from the European Union, TF50 (2017) 19, Commission to EU 27, 8-12-2017. Retrieved from: https://goo.gl/FtGqZs.

Khushal Murkens, J. E. (2017). Mixed Messages in Bottles: the European Union, Devolution, and the Future of the Constitution. Modern Law Review, 80 (4), 685-745. Available at: https://doi.org/10.1111/1468-2230.12279.

Łazowski, A. (2016). Unilateral Withdrawal from the EU: Realistic Scenario or a Folly? Journal of European Public Policy, 23, 1294-1301. Available at: https:// doi.org/10.1080/13501763.2016.1174529.

Mac Amhlaigh, C. (2017). Miller: the prerogative and constitutional change. Edinburgh Law Review, 21 (3), 448-454. Available at: https://doi.org/10.3366/ elr.2017.0443.

Mangas Martín, A. (2016). Postbrexit: Una Europa confusa, entre el Desánimo y la Incertidumbre. Revista de Derecho Comunitario Europeo, 54, 427-437.

- (2018). Postbrexit. Entre la Unión Europea necesaria y la posible. Revista de Occidente, 440, 41-61.

May, T. (2017a). The government's negotiating objectives for exiting the EU. PM speech, Lancaster House, 17-1-2017. Retrieved from: https:/goo.gl/CDuCdT.

_ Prime Minister's letter to Donald Tusk triggering Article 50, 29-3-2017. Retrieved from: https://goo.gl/Gmps 5 h.

Memorandum of Understanding. (2013). Memorandum of Understanding between the United Kingdom Government, the Scottish Ministers, the Welsh Minis- 
ters, and the Northern Ireland Executive Committee, 10-2013. Retrieved from: https://goo.gl/okFFom.

Mindus, P. (2017). European Citizenship after Brexit: Freedom of Movement and Rights of Residence. London: Palgrave Macmillan. Available at: https://doi. org/10.1007/978-3-319-51774-2.

Ministry of Justice. (2009). The Governance of Britain. Review of the Executive Royal Prerogative Powers: Final Report, 10-2009. Retrieved from: https:/goo. $\mathrm{gl} / \mathrm{GMNzFz}$.

Ostendorf, P. (2017). The withdrawal cannot be withdrawn: the irrevocability of a withdrawal notification under art. 50-2 TEU. European Law Review, 42 (5), 767-776.

Phillipson, G. (2016). A Dive into Deep Constitutional Waters: Article 50, the Prerogative and Parliament. Modern Law Review, 79 (6), 1064-1089. Available at: https://doi.org/10.1111/1468-2230.12230.

Phinnemore, D. (ed.), Galligan, McCall, C., McGowan, L. and Murphy, M. C. (2015). To Remain or Leave? Northern Ireland and the EU Referendum. EU Debate NI Research Paper. Retrieved from: https://goo.gl/aB521f.

Poole, T. (2017). Devotion to Legalism: On the Brexit Case. Modern Law Review, 80 (4), 685-745. Available at: https://doi.org/10.1111/1468-2230.12280.

Reynolds, A. (1999). A Constitutional Pied Piper: The Northern Irish Good Friday Agreement. Political Science Quarterly, 114 (4), 613-637. Available at: https:// doi.org/10.2307/2657786.

Ryan, B. (2001). The Common Travel Area between Britain and Ireland. Modern Law Review, 64 (6), 855-874. Available at: https://doi.org/10.1111/14682230.00356.

Sari, A. (2017). Reversing a withdrawal notification under article 50 TEU: can a Member State change its mind? European Law Review, 42, 451-473.

Skouris, V. (2005). The ECJ and the EFTA Court under the EEA Agreement: A Paradigm for International Cooperation between Judicial Institutions. En C. Baudenbacher, P. Tresselt and T. Örlygsson (eds.). The EFTA Court: Ten Years On (pp. 123-131). Oxford: Hart Publishing.

Sturgeon, N. (2017a). Nicola Sturgeon responds to UK Supreme Court ruling. Edinburgh, 24-1-2017. Retrieved from: https://goo.gl/ngFW3N.

- (2017b). To limit the harm done by Brexit, stay in the EU single market. The Guardian, 2-12-2017. Retrieved from: https://goo.gl/AoHD7V. and Jones, C. (2017). First Minister of Scotland and First Minister of Wales, Joint Statement on the EU (Withdrawal) Bill, 13-7-2017. Retrieved from: https://goo.gl/CjQPij.

Tatham, A. F. (1993). The Sovereignty of Parliament after Factortame. Europarecht, 28, 188-196.

(2009). Enlargement of the European Union. Alphen aan den Rijn: Kluwer Law International.

(2012). 'Don't Mention Divorce at the Wedding, Darling'! EU Accession and Withdrawal after Lisbon. En P. Eeckhout, A. Biondi and S. Ripley (eds.). European 
Union Law after the Lisbon Treaty (pp. 128-154). Oxford: Oxford University Press. Available at: https://doi.org/10.1093/acprof:oso/9780199644322.003.0006.

- (2015). "The Art of Falling Apart?”: Constitutional conundrums surrounding a potential Brexit. CSF-SSSUP Working Paper No. 2/2015. Retrieved from: https:// goo.gl/BjXyDU.

The Herald (2018). Fresh appeal to halt Brexit through the EU court. The Herald, 9-2-2018. Retrieved from: https://goo.gl/eBsYMx.

Tomkins, A. (2003). Public Law. Oxford: Oxford University Press.

- and Turpin, C. (2011). British Government and the Constitution: Text and Materials. Cambridge: Cambridge University Press.

Tonge, J. (2016). The Impact of Withdrawal from the European Union upon Northern Ireland. The Political Quarterly, 87 (3), 338-342. Available at: https://doi. org/10.1111/1467-923X.12288.

Tridimas, T. (2016). Article 50: An Endgame without an End? King's Law Journal, 27, 297-313. Available at: https://doi.org/10.1080/09615768.2016.1254418.

Wade, H. W. R. (1996). Sovereignty. Revolution or evolution? Law Quarterly Review, $112,568-575$.

Young, A. L. (2017). Case Comment. R. (Miller) v. Secretary of State for Exiting the European Union: thriller or vanilla? European Law Review, 42 (2), 280-295. 